\title{
Genetic diversity and differentiation in Patellifolia (Amaranthaceae) in the Macaronesian archipelagos and the Iberian Peninsula and implications for genetic conservation programmes
}

\author{
Lothar Frese (D) Marion Nachtigall · José María Iriondo • María Luisa Rubio Teso • \\ Maria Cristina Duarte $\cdot$ Miguel Ângelo A. Pinheiro de Carvalho
}

Received: 14 May 2018/Accepted: 8 October 2018/Published online: 24 October 2018

(C) Springer Nature B.V. 2018

\begin{abstract}
This is the first comprehensive investigation of the patterns of genetic diversity of Patellifolia species. The main objective of our research work is to determine Most Appropriate crop Wild relative Populations (MAWP) suited to conserve in situ wild relatives of the sugar beet. Individual plant samples of $P$. patellaris were collected at 26 and of $P$. procumbens/P. webbiana at seven sites and analysed with 24 and 22 microsatellite markers, respectively. On average 15 alleles per locus were found within the set of
\end{abstract}

Electronic supplementary material The online version of this article (https://doi.org/10.1007/s10722-018-0708-4) contains supplementary material, which is available to authorized users.

L. Frese $(\bowtie) \cdot$ M. Nachtigall

Julius Kühn-Institut, Federal Research Centre for Cultivated Plants (JKI), Institute for Breeding Research on Agricultural Crops, Erwin-Baur-Str. 27,

06484 Quedlinburg, Germany

e-mail: lothar.frese@julius-kuehn.de

J. M. Iriondo · M. L. Rubio Teso

Área de Biodiversidad y Conservación, Universidad Rey Juan Carlos, 28933 Móstoles, Madrid, Spain

M. C. Duarte

Centre for Ecology, Evolution and Environmental Changes (CE3C), Faculdade de Ciências, Universidade de Lisboa, Campo Grande, 1749-016 Lisbon, Portugal

M. Â. A. Pinheiro de Carvalho

ISOPlexis Genebank, Universidade da Madeira, Campus

da Penteada, 9020-105 Funchal, Madeira, Portugal
$581 P$. patellaris and an average of 12 alleles per locus in the set of $172 P$. procumbens/P. webbiana individuals. The factorial analysis showed diversity patterns which agree well with the geographic origin of the samples. The genetic data suggest that $P$. patellaris reproduces mainly by self-fertilisation while $P$. procumbens $/ P$. webbiana have the signature of outbreeders. The measure $\Delta$ was used to calculate the genetic distance of each occurrence to the pooled remaining occurrences, the complement. Occurrences with either the lowest or the highest genetic distance to the complement are particularly suited to conserve the genetic diversity of the species. Eight occurrences of $P$. patellaris, two of $\mathrm{P}$. procumbens and one for $P$. webbiana were determined according to this scheme, proposed as MAWP and recommended for the establishment of genetic reserves.

Keywords Genetic diversity · Differentiation · In situ conservation - Genetic resources · Microsatellite marker $\cdot$ Patellifolia

\section{Introduction}

The former Beta section Procumbentes Ulbr. was ranked as a separate genus Patellifolia A. J. Scott, Ford-Lloyd and J. T. Williams (Amaranthaceae) by Scott et al. (1977). Patellifolia species are important crop wild relatives (CWR) of cultivated beets (de 
Vilmorin 1923; Jung et al. 1993). One of the four groups of cultivated beets (Hammer 2001), the sugar beet (Beta vulgaris L. subsp. vulgaris culton group Sugar Beet; Lange et al. 1999), was grown on $3,091,844$ ha in Europe in the year 2014. Where the crop is grown in short crop rotations for economic reasons the pest and disease pressure increases and induces a major problem to sugar beet growers (Winner 1981).

Sugar beet breeding has been quite successful in the development of resistant varieties through introgression of novel traits from wild species into the breeding pool (Panella and Lewellen 2007). The species of the genus Patellifolia are known to possess resistance to several viruses (curly top, beet mosaic, beet necrotic yellow vein), bacteria (Erwinia spp.), fungi (Erysiphe betae (Vaňha) Weltzien, Cercospora beticola Sacc., Polymyxa betae Keskin), nematodes (Heterodera spp., Meloidogyne spp.), aphids (Myzus persicae Sulzer) or leafminer (Pegomya betae Curtis) affecting the sugar beet crop (compiled by Frese 2002a). The introgression of these traits into the cultivated beets is difficult but not impossible as exemplified by the successful transfer of the resistance against the beet cyst nematode (Heterodera schachtii Schm.) from Patellifolia species into the sugar beet by conventional breeding techniques (Löptien 1984).

According to the gene pool concept of Harlan and de Wet (1971) the genus Patellifolia forms the tertiary gene pool of cultivated beets. The genera Beta and Patellifolia started to diverge at roughly 25.3 million years ago (16.1-34.8 Mya), and currently form two clearly separated monophyletic groups (Romeiras et al. 2016) which explain the strong crossing barriers between Patellifolia species and Beta vulgaris. Following Scott et al. (1977), the genus Patellifolia consists of three species, namely Patellifolia patellaris (Moq.) A. J. Scott, Ford-Lloyd and J. T. Williams (syn. B. patellaris Moq.), Patellifolia procumbens (C. Sm.) A. J. Scott, Ford-Lloyd and J. T. Williams (syn. B. procumbens C. Sm.), and Patellifolia webbiana (Moq.) A. J. Scott, Ford-Lloyd and J. T. Williams (syn. B. webbiana Moq.). However, the difficulties in distinguishing the species lead some authors to refer an uncertain number of species-two or three (e.g. Hohmann et al. 2006; Kadereit et al. 2006) or even only one (e.g. Thulin et al. 2010, see below).

The center of diversity of the genus Patellifolia encompasses the Macaronesian archipelagos
(Madeira, Salvages, Canary Islands, Cape Verde) where all three species occur. P. patellaris is also distributed along the coastline of the Iberian Peninsula and Northwest Africa (Morocco, Algeria, and Mauritania) as well as in a few more isolated localities such as the island Linosa (Italy) and interior localities of Northwest Africa (Anonymous 2017; El Bahloul and Gaboun 2013; Romeiras et al. 2016; Thulin et al. 2010). Patellifolia species are adapted to ruderal sites and occur mainly in remnant habitat fragments along the coastline as well as road sites or in abandoned farm fields close to the sea.

Raab-Straube et al. (2016) recently listed the occurrence, in Tunisia, of Patellifolia procumbens (syn. Beta patellaris Moq. and syn. Tetragonia pentandra Balf. f.). The collectors, R. El Mokni and D. Iamonico, used the taxonomic system suggested by Thulin et al. (2010) who recognised $P$. procumbens as the only species within the genus Patellifolia. Thulin and co-workers further suggest using this system until it can be disproved by new data. The proposal of Thulin et al. (2010) is based on the analysis of ITS regions of five specimens, namely $P$. procumbens and $P$. patellaris from Gran Canaria, $P$. webbiana and $P$. patellaris from Tenerife as well as one specimen from Tetragonia pentrandra from Socotra (Yemen). While the taxonomic debate continues, we propose using the taxonomic system of Scott et al. (1977) which is also the basis used in threat assessment studies. $P$. patellaris and $P$. procumbens are categorized according to the IUCN Red List as "LC" (least concern) while $P$. webbiana is classified as "CR" (critically endangered; Bilz et al. 2011).

Most of the CWR species are not actively managed in or outside protected areas and may therefore get lost accidentally (Maxted et al. 2008). There is therefore the need to organize systematic CWR conservation programmes combining the best elements of the in situ and ex situ conservation strategy. Recently, Maxted and collaborators developed a European concept for in situ conservation where they propose the establishment of genetic reserves networks for CWR (Maxted et al. 2015). The genetic reserve conservation technique is defined as "The location, management and monitoring of genetic diversity in natural populations within defined areas designated for long-term active conservation" (Maxted et al. 1997). Following this approach and using the step by step methodology published on the CWR In situ Strategy Helpdesk 
(http://aegro.jki.bund.de), Kell et al. (2012) already identified seven sites in Europe (five in the Canaries and two in Madeira) which could qualify for the establishment of genetic reserves for Patellifolia. According to the proposed quality standards for genetic reserves, Most Appropriate crop Wild relative Populations (MAWP), a term for in situ conservation units first coined by S. Kell (Maxted et al. 2015), have to be identified through a rigorous scientific process (Iriondo et al. 2012) which includes the genetic characterization of populations of the target taxon. The genetic analysis is required to identify a number of individual MAWPs representing altogether the genetic diversity of a taxon (Maxted et al. 2015). Until recently, only few polymorphic microsatellite markers (El Bahloul and Gaboun 2013) were suited to investigate genetic diversity of Patellifolia. Nachtigall et al. (2016) developed additional microsatellite markers which were used to study genetic diversity of $P$. patellaris from the Iberian Peninsula (Frese et al. 2017a). The results of a comprehensive analysis of all occurrences of $P$. patellaris and $P$. procumbens $/ P$. webbiana sampled in major parts of the distribution area are presented here. The main objective of our research work is to determine MAWPs of Patellifolia species.

\section{Materials and methods}

According to the definition of Kleinschmit et al. (2004) a collection of individual plants can only be denoted population if the individuals form a reproductively coherent group within spatial limits. The establishment of a reproductively coherent plant group is a task that cannot be performed in exploratory projects such as the one presented here. It requires the establishment of time series data (Kleinschmit et al. 2004). Therefore, the term "occurrence" is used in this paper in place of the term "population." Occurrence is defined as a collection of individuals growing at a specific locality.

\section{Sampling of leaf material}

The shortest distance from Madeira to the Canary Islands, the east coast of Iberia Peninsula and the Cape Verde Islands is approximately $500 \mathrm{~km}, 1700 \mathrm{~km}$ and $2100 \mathrm{~km}$, respectively. The task of collecting plant material was therefore shared by project partners and supported by travel funds provided by the European Cooperative Programme for Plant Genetic Resources (ECPGR, Rome) in the year 2015. Distribution data of Patellifolia taxa were downloaded from the Global Biodiversity Information Facility (GBIF 2015), the International Database for Beta (IDBB 2015), the Genetic Resources Information Network (GRIN 2015) and the EURISCO Web Catalogue (EURISCO 2015) and compiled. This data set and in particular the knowledge of local experts was used to identify potential growing sites of Patellifolia. The localities were visited by project partners to take plant samples. Further details on the collecting mission are reported by Frese et al. (2017b). Information on the geographic origin of the sampled plant species and the material codes used in tables and figures is given in Table 1. A leaf sample of $0.5-1 \mathrm{~g}$ fresh weight was taken from up to 40 individual plants per site, stored separately and dried in silica gel in tea filter bags. When possible, plants were sampled at a distance of $2 \mathrm{~m}$ between individuals so as to minimize kinship. The leaf samples were processed in a standardized manner for molecular analysis in the Julius Kühn-Institut.

\section{Laboratory analysis}

Genomic DNA was extracted from dried (20 mg) leaf material after vigorous homogenization in a mixermill disruptor according to the modified CTAB protocol (Saghai-Maroof et al. 1984). DNA amplification was carried out in a total volume of $10 \mu \mathrm{L}$. The fluorescent dye labelling of PCR products in one reaction was performed with three primers. The PCR mix contained $25 \mathrm{ng}$ template DNA, $1.5 \mathrm{mM} \mathrm{MgCl}_{2}$, $200 \mu \mathrm{M}$ of each dNTP, $0.05 \mu \mathrm{M}$ of a sequencespecific forward primer with M13 tail at its 5' end, $0.17 \mu \mathrm{M}$ of a sequence-specific reverse primer, $0.035 \mu \mathrm{M}$ of the universal fluorescent-labelled (dye: D2, D3, D4) M13 primer and 0.5 U Taq DNA polymerase. Thus, a multiplexing could be performed depending on the marker. A touch-down PCR profile was generally used as described by Nachtigall et al. (2016). The microsatellite analysis was conducted using a capillary electrophoresis GenomeLab ${ }^{\mathrm{TM}}$ GeXP Genetic Analysis System (Sciex). Fragment sizes were determined and documented in a database developed by Enders (2010). The analysis of a probe was once repeated in case of the absence of a fragment. 
Table 1 Identifiers and geographic origin of the occurrences

\begin{tabular}{|c|c|c|c|c|c|c|}
\hline $\begin{array}{l}\text { Population } \\
\text { identified }\end{array}$ & $\begin{array}{l}\text { Origin } \\
\text { country FAO } \\
\text { ISO3 code }\end{array}$ & $\begin{array}{l}\text { Location } \\
\text { of the site }\end{array}$ & $\begin{array}{l}\text { Site } \\
\text { code }\end{array}$ & $\begin{array}{l}\text { Region } \\
\text { code used } \\
\text { in Fig. } 1\end{array}$ & $\begin{array}{l}\text { Legend used in } \\
\text { Figs. } 3 \text { and } 4 \text {, } \\
\text { and Supplement } \\
\text { 1a and } 2\end{array}$ & $\begin{array}{l}\text { Legend used in } \\
\text { Figs. } 2,5 \text { and } 6 \text {, } \\
\text { and Supplement } \\
1 \text { b and } 3\end{array}$ \\
\hline
\end{tabular}

\begin{tabular}{|c|c|c|c|c|c|c|}
\hline \multirow[b]{2}{*}{ AZO2403151630 } & \multicolumn{6}{|c|}{$P$. patellaris } \\
\hline & ESP & Murcia & $\mathrm{AZO}$ & IBE & 1 & - \\
\hline BAL2104150900 & ESP & Almería & BAL & IBE & 2 & - \\
\hline CV.SV.BG-1 & $\mathrm{CPV}$ & Cape Verde, São Vicente Island & BG & CAP & 3 & - \\
\hline CGO3103151000 & ESP & Málaga & CGO & IBE & 4 & - \\
\hline CLM0707151601 & PRT & Madeira & $\mathbf{C L}$ & MAD & 5 & - \\
\hline CNE2303151030 & ESP & Murcia & CNE & IBE & 6 & - \\
\hline COL2005151000 & ESP & Castellón & $\mathrm{COL}$ & IBE & 7 & - \\
\hline СТМ0707151415 & PRT & Madeira & CT & MAD & 8 & - \\
\hline FM-1 & PRT & Setúbal & FM & IBE & 9 & - \\
\hline FXM0707151719 & PRT & Madeira & FX & MAD & 10 & - \\
\hline $\mathrm{H}$ & ESP & La Gomera & $\mathrm{H}$ & CAN & 11 & - \\
\hline HS & ESP & El Hierro & HS & CAN & 12 & - \\
\hline MOR0903151000 & ESP & Alicante & MOR & IBE & 13 & - \\
\hline PCA3003151000 & ESP & Málaga & PCA & IBE & 14 & - \\
\hline PPL & ESP & La Palma & PPL & CAN & 15 & - \\
\hline PS-1 & PRT & Faro & PS & IBE & 16 & - \\
\hline PSM2704151936 & PRT & Madeira & PS32 & MAD & 17 & - \\
\hline CV.SV.RSJ-1 & $\mathrm{CPV}$ & Cape Verde, São Vicente Island & RSJ & CAP & 18 & - \\
\hline $\mathrm{S}$ & ESP & La Gomera & $\mathrm{S}$ & CAN & 19 & - \\
\hline STE2104151800 & ESP & Almería & STE & IBE & 20 & - \\
\hline TES & ESP & Tenerife & TES & CAN & 21 & - \\
\hline TLG & ESP & Tenerife & TLG & CAN & 22 & - \\
\hline TLS & ESP & Tenerife & TLS & CAN & 23 & - \\
\hline TPA & ESP & Tenerife & TPA & CAN & 24 & - \\
\hline ТРH0604151200 & ESP & Tenerife & $\mathrm{TPH}$ & CAN & 25 & - \\
\hline \multirow[t]{2}{*}{ TPM } & ESP & Tenerife & TPM & CAN & 26 & - \\
\hline & \multicolumn{6}{|c|}{ P. procumbens/P. webbiana } \\
\hline- & ESP & Gran Canaria & PWGI & - & - & 1 \\
\hline TAL & ESP & Tenerife & TAL & - & - & 2 \\
\hline TBA & ESP & Tenerife & TBA & - & - & 3 \\
\hline TGA & ESP & Tenerife & TGA & - & - & 4 \\
\hline TPC & ESP & Tenerife & $\mathrm{TPC}$ & - & - & 5 \\
\hline ТРH0604151144 & ESP & Tenerife & TPH & - & - & 6 \\
\hline TPS & ESP & Tenerife & TPS & - & - & 7 \\
\hline
\end{tabular}

The descriptor "population identifier" and "site code" was used in the final report of the GeDiPa project (Frese et al. 2017b) and is listed here as a reference. Site codes printed in bold letter indicate the locality of recommended genetic reserves

If the fragment remained absent, the allele was recorded as a null allele.

Twenty-six occurrences of $P$. patellaris with a total number of 581 individuals were analysed using 24 markers. Furthermore, six occurrences of $P$. procumbens plus one $P$. webbiana summing up to a total number of 172 plants were analysed with 22 markers. 
The complete data sets were published separately as open access files (Nachtigall et al. 2018).

Statistical analysis

The microsatellite markers used in the present study were all derived from genomic sequences of diploid $P$. procumbens (Nachtigall et al. 2016). Statistical procedures for diploid species were therefore employed in subsequent statistical analyses. The ALLELE procedure of SAS (version 9.3) was used to calculate the number of alleles per SSR locus over all occurrences and the polymorphic information content of the SSR loci. For each occurrence/SSR marker combination the deviation from the Hardy-Weinberg principle (HWP) was tested with the $\mathrm{Chi}^{2}$-Test and the result either indicated as HWE (in equilibrium) or HWD (in disequilibrium). Factorial analysis (Software Darwin, Perrier and Jacquemound-Collet 2006) was applied to identify variation patterns in the $P$. patellaris as well as $P$. procumbens/P. webbiana dataset and to learn if the variation patterns agree with the geographic origin of the individuals. All data including null alleles were used.

Nei's measure of diversity (Nei 1973) as well as F-statistics (Weir and Cockerham 1984) and derived measures have been widely used to illustrate genetic relationships among populations. These measures reflect only the differences in the relative frequencies of the trait states and do not consider quantitative differences in trait states. To overcome this problem, Gregorius et al. (2003) developed the difference measure $\Delta$ that is based on both frequency and trait differences. The measure $\Delta$ has a number of advantages compared to commonly used measures as explained and comprehensively discussed by Gillet and Gregorius (2008), Gillet (2013) and Gregorius et al. (2014). It allows inter alia the analysis of differentiation among occurrences at different levels of genic integration. In addition, the genetic distance measure $\Delta$ is free of assumptions such as the presence of the HWE in panmictic ideal populations and its subpopulations.
For a specific trait and a pair of populations, the pairwise genetic distance ( $\Delta)$ equals the minimal extent to which the genetic types (e.g., alleles of a gene) of individuals in one population must be altered to obtain the composition of genetic types in the other (Gillet and Gregorius 2008). The measure $\Delta$ can be used to calculate the complementary compositional differentiation within a set of several populations whereby $\Delta_{\mathrm{j}}$ is the contribution of the jth population to genetic differentiation. It is the genetic distance of the jth population to the pooled remainder ("the complement"). $\Delta_{\mathrm{SD}}$ quantifies the average degree to which all populations differ from their complements. This approach is applicable to co-dominant marker data sets (Gillet 2013).

The genetic distance measure $\Delta$ considers trait differences (Gregorius et al. 2003), i.e. fragment size in case of the Patellifolia research project. As null alleles are coded with 999, which would represent the largest possible fragment size, all individuals having a null allele at any of the loci were excluded from the dataset prior to genetic analysis. The software DifferInt (Gillet 2013) was used to calculate the pairwise genetic distance $\Delta$ between two occurrences as well as $\Delta_{\mathrm{j}}$ and $\Delta_{\mathrm{SD}}$. The matrix of $\Delta$ values was loaded into DARwin to construct an UPGMA tree illustrating the genetic relationships between occurrences. Distance and differentiation measures as well as the UPGMA tree were obtained for three levels of genic integration, namely the gene pool (GP) level, i.e. all alleles at one or more loci and the single-locus (SL) level (singlelocus genotypes). These two are characterized by locus and allelic state. The highest level of genic integration is the multi-locus (ML) level. The multilocus genotypes (individual plants) are characterized by the allelic states at all loci (Gillet 2013).

Ten thousand new data sets were generated by random permutation of all genes (alleles) at each locus among the individuals within each occurrence. In a second permutation analysis all individuals together with their multi-locus types were randomly permuted among the populations. The results of the permutation 
analyses were used to test hypothesis on forces involved in differentiations.

\section{Results}

Descriptive genetic parameter

Within the total set of $P$. patellaris marker data (581 plants, 24 marker; 27,936 data points) 434 null alleles were detected. The number of null alleles found in the $P$. patellaris material decreased to 390 after exclusion of JKIPat02 and JKIPat03, the marker loci which did not function well in $P$. procumbens/P. webbiana. Only 82 null alleles were recorded for $P$. procumbens $/ P$. webbiana (172 plants, 22 marker; 7568 data points). If calculated over the 22 markers commonly used for analyzing both groups of material, $1.52 \%$ of null alleles were observed for $P$. patellaris as compared to $1.08 \%$ in $P$. procumbens/P. webbiana. Marker loci JKIPat06, JKIPat07, JKIPat10, JKIPat21, JKIPat22, JKIPat24, JKIPat25, and JKIPat26 produced no null alleles in $P$. procumbens/P. webbiana at all. All markers were derived from a $P$. procumbens sequence (Nachtigall et al. 2016) which explains the lower percentage of null alleles observed in the set of $P$. procumbens/P. webbiana plants.

The range of allele size described by Nachtigall et al. (2016), the observed range, the number of alleles at each locus and the polymorphic information content values (PIC) are presented in Table 2. In P. patellaris the number of alleles ranged from 4 to 29 , the PICvalue from 0.2722 to 0.8711 , the observed heterozygosity from 0.0223 to 0.9742 and the expected heterozygosity from 0.2900 to 0.8823 . Within the set of $P$. procumbens/P. webbiana the number of alleles ranged from 4 to 24 , the PIC-value from 0.3289 to 0.9047 , the observed heterozygosity from 0.2500 to 0.8663 and the expected heterozygosity from 0.3905 to 0.9112 . In total 359 alleles with an average of 15 alleles per locus were detected in P. patellaris and 264 alleles with an average of 12 alleles per locus were observed in the smaller set of $P$. procumbens $/ P$. webbiana.

In $P$. patellaris the average percentage of invariant "occurrence/marker" combinations was $15.5 \%$. The percentage of combinations in HWE ranged between 0.0 and $58.3 \%$ with an overall average of $14.6 \%$. The overall average of all combinations in HWD was
69.4\%. Contrary to $P$. patellaris all "occurrence/marker" combinations of $P$. procumbens $/ P$. webbiana were variable. The percentage of marker loci per occurrence showing HWE ranged between 31.8 and $59.1 \%$ and the overall average of all "occurrence/marker" combinations in HWE or HWD was $50.6 \%$ and $49.4 \%$, respectively (Supplement 1a, b). Because all of the Patellifolia samples used in this study did not match the criteria of random mating plant groups in HWE, the measure $\Delta$ was chosen for statistical analysis.

Structures of phenotypic diversity

The results of the factorial analysis of the $P$. patellaris data set (581 individuals $\times 24$ markers) are presented in Fig. 1. The x-axis explains $28.2 \%$ and the $y$-axis $6.8 \%$ of the variation. The individuals were assigned to the four geographic groups (Table 1) that are isolated by the Atlantic Ocean by several hundreds of kilometres, i.e. the Iberian Peninsula, Madeira, the Canary Islands and Cape Verde Islands. The distribution pattern of individuals in the scatter plot coincides well with the geographic origin of the sampled plants. The material from the Iberian Peninsula is separated into plants sampled in Portugal and a larger group distributed from South to East Spain. Plants from Tenerife, La Palma and La Gomera form a swarm, whereas the samples from El Hierro form a separate cloud. The individuals from Madeira are interspersed with those from Tenerife, La Gomera and La Palma. Finally, the individuals from Cape Verde Islands form a distinct group but weakly separated from that composed by individuals from Tenerife, La Gomera, La Palma and Madeira.

Figure 2 displays the results for $P$. procumbens $/ P$. webbiana (172 individual $\times 22$ markers). The $y$-axis explains $11.6 \%$ and the $x$-axis $6.1 \%$ of the total variation. As observed for $P$. patellaris, the patterns of $P$. procumbens $/ P$. webbiana coincide well with the geographic origin of the sampled individuals. The dots located in the left part of the figure represent $P$. webbiana individuals collected in Gran Canaria at La Isleta. The dots in the right part of the scatter plot all represent $P$. procumbens. All plants from three sites of the northern coastline of Tenerife form a swarm (occurrences no. 2, 3, 7 in Fig. 2). Occurrence 6, also located on the northern coastline, forms a separate group as do the groups from north-eastern (occurrence 
Table 2 Motif, reported (Nachtigall et al. 2016) and observed allele range, number of alleles per marker loci (NoA), polymorphic information content (PIC), observed heterozygosity $\left(\mathrm{H}_{\mathrm{o}}\right)$ and expected heterozygosity $\left(\mathrm{H}_{\mathrm{e}}\right)$

\begin{tabular}{|c|c|c|c|c|c|c|c|c|c|c|c|c|}
\hline Locus & Motif & $\begin{array}{l}\text { Range } \\
\text { reported }\end{array}$ & $\begin{array}{l}\text { Range } \\
\text { observed }\end{array}$ & NoA & PIC & $\mathrm{H}_{\mathrm{o}}$ & $\mathrm{H}_{\mathrm{e}}$ & $\begin{array}{l}\text { Range } \\
\text { observed }\end{array}$ & NoA & $\mathrm{PIC}$ & $\mathrm{H}_{\mathrm{o}}$ & $\mathrm{H}_{\mathrm{e}}$ \\
\hline & & & \multicolumn{5}{|c|}{ P. patellaris } & \multicolumn{5}{|c|}{ P. procumbens/P. webbiana } \\
\hline JKIPat01 & $(\mathrm{GA})_{8}$ & $170-191$ & $162-220$ & 13 & 0.6973 & 0.0309 & 0.7361 & $186-200$ & 8 & 0.7547 & 0.2558 & 0.7858 \\
\hline JKIPat02 & $(\mathrm{CA})_{8}$ & $196-227$ & $163-256$ & 13 & 0.3905 & 0.2027 & 0.3997 & $*$ & & & & \\
\hline JKIPat03 & $(\mathrm{TG})_{19}$ & $198-231$ & $208-254$ & 26 & 0.8486 & 0.9038 & 0.8622 & $*$ & & & & \\
\hline JKIPat04 & $(\mathrm{CT})_{8}$ & $216-228$ & $221-249$ & 15 & 0.8711 & 0.7612 & 0.8823 & $233-249$ & 8 & 0.5771 & 0.4477 & 0.6207 \\
\hline JKIPat05 & $\begin{array}{l}(\mathrm{GT})_{8} \\
\quad(\mathrm{GA})_{16}\end{array}$ & $181-232$ & $197-263$ & 11 & 0.5500 & 0.6804 & 0.5885 & $224-256$ & 16 & 0.7478 & 0.8314 & 0.7734 \\
\hline JKIPat06 & $(\mathrm{AG})_{24}$ & $161-197$ & $132-226$ & 20 & 0.6690 & 0.7801 & 0.6981 & $178-225$ & 24 & 0.9047 & 0.6395 & 0.9112 \\
\hline JKIPat07 & $(\mathrm{TC})_{8}$ & $173-179$ & $168-290$ & 14 & 0.3835 & 0.4966 & 0.4481 & $187-197$ & 7 & 0.6902 & 0.5523 & 0.7298 \\
\hline JKIPat08 & $(\mathrm{AG})_{8}$ & $183-193$ & $194-227$ & 12 & 0.3760 & 0.0223 & 0.3867 & $191-211$ & 10 & 0.5942 & 0.3023 & 0.6270 \\
\hline JKIPat10 & $(\mathrm{CA})_{6}$ & $164-169$ & $172-223$ & 10 & 0.2722 & 0.0361 & 0.2900 & $181-189$ & 4 & 0.5627 & 0.4012 & 0.6335 \\
\hline JKIPat11 & $(\mathrm{TC})_{11}$ & $157-184$ & $142-214$ & 25 & 0.7938 & 0.2010 & 0.8143 & $159-224$ & 22 & 0.7463 & 0.2500 & 0.7595 \\
\hline JKIPat12 & $(\mathrm{AG})_{9}$ & $165-191$ & $180-217$ & 14 & 0.6510 & 0.8797 & 0.6867 & $182-231$ & 20 & 0.8725 & 0.5116 & 0.8824 \\
\hline JKIPat13 & $\begin{array}{l}(\mathrm{CA})_{2} \\
\quad(\mathrm{GA})_{8}\end{array}$ & $151-179$ & $166-211$ & 25 & 0.8551 & 0.9364 & 0.8683 & $169-217$ & 18 & 0.8875 & 0.4826 & 0.8951 \\
\hline JKIPat14 & $(\mathrm{AC})_{8}$ & $219-223$ & $218-262$ & 16 & 0.7117 & 0.1890 & 0.7380 & $214-261$ & 16 & 0.6623 & 0.4884 & 0.6846 \\
\hline JKIPat15 & $(\mathrm{GT})_{10}$ & $174-192$ & $174-232$ & 29 & 0.8194 & 0.9742 & 0.8378 & $190-210$ & 10 & 0.8349 & 0.5988 & 0.8509 \\
\hline JKIPat17 & $(\mathrm{CT})_{14}$ & $188-202$ & $203-217$ & 9 & 0.5086 & 0.0344 & 0.5872 & $148-217$ & 11 & 0.7119 & 0.3140 & 0.7310 \\
\hline JKIPat18 & $\begin{array}{l}(\mathrm{TG})_{8} \\
\quad(\mathrm{AG})_{4}\end{array}$ & $177-191$ & $167-235$ & 11 & 0.4885 & 0.0790 & 0.5781 & $195-226$ & 10 & 0.6651 & 0.5407 & 0.6963 \\
\hline JKIPat19 & $(\mathrm{GGAT})_{8}$ & $203-258$ & $182-284$ & 16 & 0.7015 & 0.9450 & 0.7277 & $203-279$ & 14 & 0.8705 & 0.7384 & 0.8818 \\
\hline JKIPat20 & $(\mathrm{TCTT})_{9}$ & $231-256$ & $236-264$ & 9 & 0.6920 & 0.0979 & 0.7366 & $228-297$ & 17 & 0.7714 & 0.6279 & 0.7950 \\
\hline JKIPat21 & $(\mathrm{GGAA})_{7}$ & $175-195$ & $173-230$ & 13 & 0.7552 & 0.8969 & 0.7884 & $202-218$ & 4 & 0.3289 & 0.4128 & 0.3905 \\
\hline JKIPat22 & $(\mathrm{GAAA})_{3}$ & $130-148$ & $147-165$ & 4 & 0.3898 & 0.6443 & 0.4784 & $147-216$ & 6 & 0.5449 & 0.8663 & 0.6203 \\
\hline JKIPat23 & $\begin{array}{l}(\mathrm{TA})_{8} \\
\quad(\mathrm{GATA})_{5}\end{array}$ & $185-224$ & $167-319$ & 12 & 0.4479 & 0.0275 & 0.4735 & $190-278$ & 14 & 0.8429 & 0.4012 & 0.8588 \\
\hline JKIPat24 & $(\mathrm{ATTC})_{7}$ & $182-214$ & $208-232$ & 9 & 0.4102 & 0.4897 & 0.4769 & $207-233$ & 9 & 0.7317 & 0.6919 & 0.7683 \\
\hline JKIPat25 & $(\mathrm{GTGA})_{9}$ & 179-195 & $177-310$ & 12 & 0.7258 & 0.7199 & 0.7631 & $191-211$ & 6 & 0.6973 & 0.4826 & 0.7419 \\
\hline JKIPat26 & $\begin{array}{l}(\mathrm{GA})_{9} \\
\quad(\mathrm{TAGA})_{3}\end{array}$ & $159-191$ & $156-273$ & 21 & 0.6542 & 0.7973 & 0.6827 & $156-184$ & 10 & 0.4757 & 0.5233 & 0.5690 \\
\hline
\end{tabular}

The number of individuals used to calculate the observed marker features is 581 for $P$. patellaris and 172 for $P$. procumbens/P. webbiana. *In $P$. procumbens/P. webbiana JKIPat02 and JKIPat03 caused too many irregular laboratory results and were therefore excluded from further analysis

no. 4) and south-western Tenerife (occurrence no. 5 in Fig. 2).

Analysis of genetic diversity

The number of individuals in the $P$. patellaris data set decreased from 581 to 458 and in the data set of $P$. procumbens/P. webbiana from 172 to 145 after exclusion of individuals having a null allele at any of the marker loci.

\section{P. patellaris}

The results of the permutation analysis for P. patellaris are presented in Table 3 . The $\Delta_{\mathrm{SD}}$ values within the $95 \%$ confidence interval generated by 10,000 permutations are significantly lower $(p=0.0018)$ than the observed $\Delta_{\mathrm{SD}}$ value of 0.4862 at the mean singlelocus level. This result indicates that the association of alleles within single loci depends on the type of alleles present in the occurrence and that the occurrences 


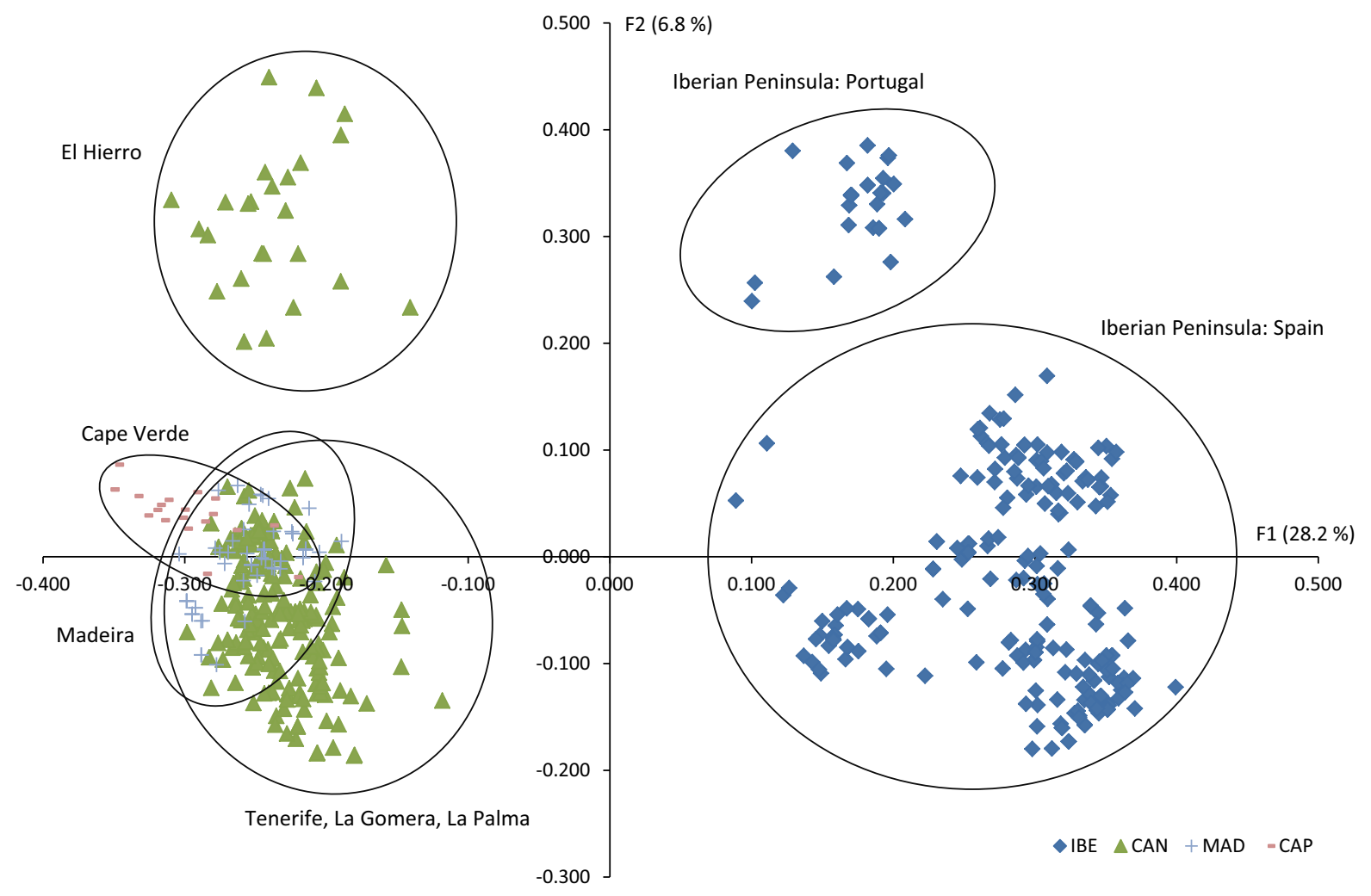

Fig. 1 Factorial analysis for P. patellaris. Factorial coordinates were calculated from dissimilarity values. IBE = Iberian Peninsula, two occurrences from Portugal, eight occurrences

differ significantly in the form of homologous association of genes. In other words, the $\Delta_{\mathrm{SD}}$ can increase only if a fraction of individual loci within single occurrences higher than the observed would be heterozygous and would allow the generation of new single-locus genotypes through permutation. The genes were also randomly combined to multi-locus types and the observed distance compared to the $\Delta_{\mathrm{SD}}$ values generated by 10,000 permutations. The $\Delta_{\mathrm{SD}}$ values within the $95 \%$ confidence interval are significantly higher $(p=1.0)$ than the observed $\Delta_{\mathrm{SD}}$ value of 0.5144 at the multi-locus level. It indicates that forces restrict the formation of new multi-locus genotypes within the observed occurrence.

Self-fertilisation appears to take place at each locality at a higher rate than expected by chance. In addition, within the set of 458 individuals, 360 distinct multi-locus genotypes were observed. Individual genotypes were represented twice up to eightfold (a from Spain; CAN = Canary Islands, Spain, ten occurrences; MAD = Madeira, Portugal, four occurrences; CAP = Cape Verde Republic, two occurrences

total of 98 duplicated genotypes) indicating preferential self-fertilization in $P$. patellaris.

To test the hypothesis that individuals associate with occurrences independently of their genetic type at a given level of integration, individuals were randomly permuted among the occurrences. The $\Delta_{\mathrm{SD}}$ values are significantly lower than the observed ones at all integration levels. The difference between the maximal $\Delta_{\text {SD }}$ generated by permutation and the observed $\Delta_{\mathrm{SD}}$ is high (gene pool level: 0.2684 , mean singlelocus level: 0.2639, multi-locus level: 0.2007) for all integration levels. This finding indicates a combined effect of genes and their associations on differentiation (Gillet 2013).

The pairwise genetic distance $(\Delta)$ ranged between 0.1783-0.9157 (gene pool level), 0.1901-0.9184 (mean single-locus level) and 0.2481-0.9178 (multilocus level). The differences between occurrences are indeed pronounced as visualised by the UPGMA trees presented in Supplement 2. The trees reflect the 


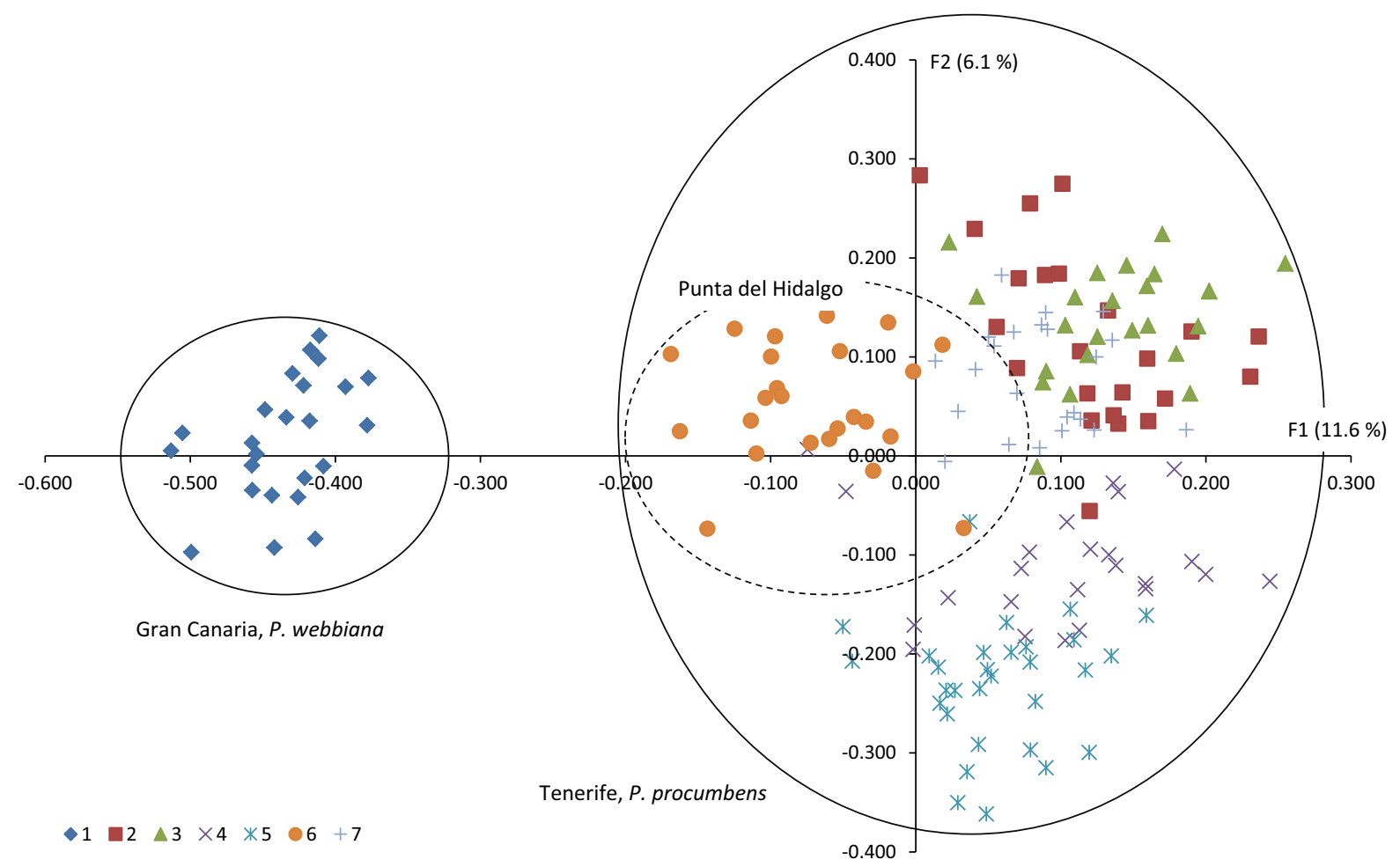

Fig. 2 Factorial analysis for $P$. procumbens and $P$. webbiana. Factorial coordinates were calculated from dissimilarity values. Numbers shown next to the symbols refer to occurrence no. 1-7 (see Table 1)

matrices of pairwise genetic distance calculated for the gene pool, mean single-locus and multi-locus level of genic integration.

Figure $3 a-c$ illustrates the differentiation within the set of $P$. patellaris occurrences. The mean complementary compositional differentiation increased from the gene pool $\left(\Delta_{\mathrm{SD}}=0.472 ; 100 \%\right)$, the mean singlelocus $\left(\Delta_{\mathrm{SD}}=0.486 ; 103 \%\right)$ to the multi-locus level $\left(\Delta_{\mathrm{SD}}=0.514 ; 109 \%\right)$. At the gene pool level occurrence no. 12 (El Hierro) surmounts the mean differentiation, i.e. the genetic diversity contained in the remaining pooled 25 occurrences (marked by the circle) while occurrence no. 21 , located in Tenerife, best represents the genetic diversity of its complement. Between these two extremes the remaining occurrences are sorted clockwise according to their $\Delta_{\mathrm{j}}$ values in decreasing order.

Occurrences representing the complement perfectly are characterised by $\Delta_{\mathrm{j}}=0$ while occurrences sharing none of the genetic types with the complement in common are indicated by $\Delta_{\mathrm{j}}=1$.

As shown in Fig. $3 a-c$ the ranking of occurrences changes with increasing level of genic integration. To test that the changed ranking is not just a random effect, the same set of random permutations of genes within populations was used to calculate the covariation of contributions to differentiation of occurrences between integration levels. High and positive covariation of $\Delta_{\mathrm{j}}$ values for all pairs of integration levels show that no form of association completely overturns the ranking prescribed by the gene pool (Gillet and Gregorius 2008). The results are given in the lower part of Table 3. The covariation is strong, positive and significant.

\section{P. procumbens/P. webbiana}

The alleles in $P$. procumbens $/ P$. webbiana are arranged to single-locus types and to multi-locus types at random as indicated by the values of $p=0.2642$ and $p=0.2375$, respectively (Table 4). This type of genic association can be explained by mainly random combination of alleles to genotypes and the mainly random combination of single loci to multi-locus genotypes. The set of 145 analysed plants was composed of 144 distinct multi-locus types. 
Table 3 P. patellaris. Permutation analysis of alleles over individuals within occurrences, of all individual genotypes among occurrences and the covariation of differentiation

\begin{tabular}{|c|c|c|c|c|c|}
\hline Permutations & $\begin{array}{l}\text { Observed } \\
\Delta_{\mathrm{SD}} \text { values }\end{array}$ & Min & $\begin{array}{l}0.95 \text { confidence } \\
\text { interval }\end{array}$ & Max & $p$ value \\
\hline \multicolumn{6}{|l|}{ Alleles over individuals within occurrences } \\
\hline Gene pool level & 0.4719 & & Not affected & & \\
\hline Mean single locus genotypes & 0.4862 & 0.4827 & $0.4836 ; 0.4857$ & 0.4866 & $0.0018 * *_{-}>$ \\
\hline Multilocus genotypes & 0.5144 & 0.5485 & $0.5503 ; 0.5529$ & 0.5543 & $1.0000 * *<-$ \\
\hline \multicolumn{6}{|l|}{ All individual genotypes between occurrences } \\
\hline Gene pool level & 0.4719 & 0.1561 & $0.1804 ; 0.2042$ & 0.2035 & $0.0000 * *_{-}>$ \\
\hline Mean single locus genotypes & 0.4862 & 0.1725 & $0.1804 ; 0.2042$ & 0.2223 & $0.0000 * *_{-}>$ \\
\hline Multilocus genotypes & 0.5144 & 0.2635 & $0.2729 ; 0.2968$ & 0.3137 & $0.0000 * *_{-}>$ \\
\hline Covariation of differentiation & Observed covariation value & & & & \\
\hline Gene pool versus mean single locus level & 1 & Undefined & $* * * * * * ; * * * * * *$ & undefined & $1.0000 * *<-$ \\
\hline Gene pool versus multilocus level & 0.9974 & 0.9970 & $* * * * * * ; * * * * * *$ & undefined & $1.0000 * *<-$ \\
\hline Mean single locus versus multilocus level & 0.9977 & 0.9900 & $0.9927 ; 0.9970$ & 0.9987 & $0.0039 * *_{-}>$ \\
\hline
\end{tabular}

The values are based on 10,000 permutations for all 24 loci. The observed $\Delta_{\mathrm{SD}}$ value is shown for the three integration levels. The calculated minimum and maximum $\Delta_{\mathrm{SD}}$ values, the $95 \%$ confidence interval as well as the permutation $(p)$ values are shown. The symbols $* *_{-}>$(upper part of the distribution) and $* *<-$ (lower part of the distribution) indicate that fewer than $1 \%$ and more than $99 \%$ of the permutations yielded $\Delta_{\mathrm{SD}}$ values that are significantly equal or greater than the observed distance. $* * p \leq 0.01$

DifferInt generates a list of distinct multi-locus types which are labelled with a sequence number. Except for sequence number 53, the genotype of plant number 18 and 19 of occurrence no. 3 growing next to each other at the collecting site Bajamar in Tenerife, all of the multi-locus types represent a unique arrangement of the alleles. Thus, it appears that outbreeding is the preferential mode of reproduction of $P$. procumbens/ P. webbiana.

The individuals associate with occurrences independently of their genetic type, as already described for $P$. patellaris. The $\Delta_{\mathrm{SD}}$ values generated by permutation are significantly lower than the observed ones at all integration levels. The difference between the maximal $\Delta_{\mathrm{SD}}$ generated by permutation and the observed $\Delta_{\mathrm{SD}}$ is high (gene pool level: 0.2077, mean single-locus level: 0.1836, multi-locus level: 0.0984) for all integration levels. This finding indicates a combined effect of genes and their associations on differentiation.

The pairwise genetic distances $(\Delta)$ ranged between 0.3498 and 0.6881 at the gene pool level, between 0.3696 and 0.6983 at the mean single-locus level, and between 0.5114 and 0.7528 at the multi-locus level. The cluster diagrams representing the genetic distances at all three levels of genic integration are given in Supplement 3.

The complementary compositional differentiation values $\Delta_{\mathrm{j}}$ varied from 0.3349 to 0.5907 (gene pool level), from 0.3702 to 0.6030 (mean single-locus level) and from 0.5557 to 0.7110 (multi-locus level). With increasing level of integration, the mean differentiation increased from the gene pool $\left(\Delta_{\mathrm{SD}}=0.4258\right.$; $100 \%)$, the mean single-locus $\left(\Delta_{\mathrm{SD}}=0.4477 ; 105 \%\right)$ to the multi-locus level $\left(\Delta_{\mathrm{SD}}=0.6049 ; 142 \%\right)$. At all levels occurrence no. 7 in Tenerife represents the composition of its complement best, while occurrence no 1 in Gran Canaria followed by occurrence no. 6 in Tenerife deviate stronger from their complements (Fig. 4a-c).

The strong and significant covariation for all pairs of integration levels show that the ranking of occurrence does not change with increasing level of genic integration. The differentiation snails (Fig. 4) illustrate this finding.

\section{Discussion}

Although plant breeding researchers and conservation biologists belong to different scientific communities 


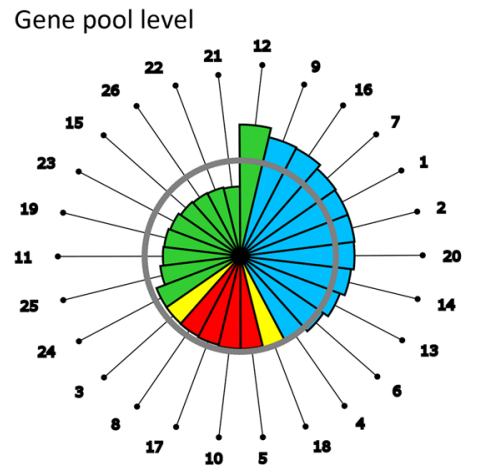

Mean single-locus level
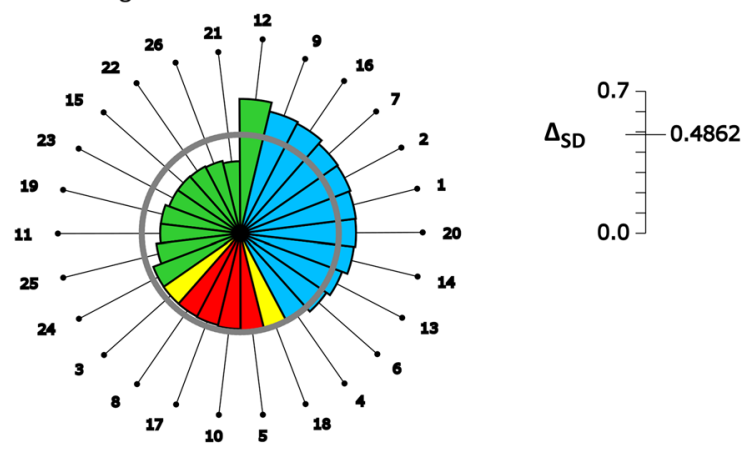

Multi-locus level
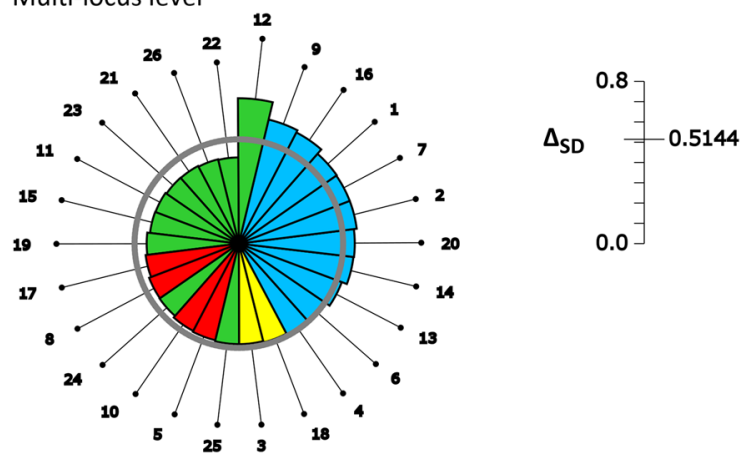

Fig. 3 Snail diagrams showing the differentiation between occurrences of $P$. patellaris at the genepool (a), mean singlelocus (b) and multi-locus (c) level. The geographic origin of the occurrences is depicted by colours (green: Canaries; blue: Iberian Peninsula; yellow: Cape Verde; red: Madeira). For more detail on occurrence numbers see Table 1. A sector illustrates one of the occurrences. The radius of its sector equals the contribution of this occurrence to differentiation. The sectors are arranged according to the radius length clockwise in decreasing order starting with the largest radius at 12:00 h. The grey circle (e.g. Figure 3 ) is equal to the weighted mean of the sector radii and marks $\Delta_{\mathrm{SD}}$. The $\Delta_{\mathrm{SD}}$-value is also shown on the bar next to the snail graph

they share a common interest: the conservation of CWR. Plant breeders need to know to what extent anthropogenic climate change induced genetic erosion within CWR (Parmesan and Hanley 2015; AguirreGutiérrez et al. 2017) will gradually diminish resources for breeding. Conservation biologists need to understand how loss of biological diversity including the intraspecific diversity will affect ecosystem functions. Both communities are interested to halt the loss of genetic diversity. The establishment of a network of genetic reserves for crop wild relatives was already described by nature conservationists as a new and useful module of species conservation programmes, as each established network will alleviate pressure on species that are not yet threatened (Zehm and Weber 2013).

This study has been implemented to provide species conservation agencies with information on localities suited for the establishment of genetic reserves. The selection of MAWP is still a challenge to the supporters of the genetic reserve conservation approach as the data basis required to take informed decisions is only slowly developing. It concerns the availability of comprehensive European inventories of georeferenced occurrences of CWR and information on the geographic patterns of genetic diversity of a species as well. The geographic patterns of genetic diversity are the result of the interplay between the species breeding system, demographic processes such as extinction and re-colonization events, and environmental factors which determine the survival and reproduction rate of genotypes best adapted to local conditions (see reviews of Eriksson et al. 1993; Manel et al. 2003).

\section{Breeding system}

The measure $\Delta$ was used to test assumptions on the mode of reproduction of Patellifolia species. Frese et al. (2017a) interpreted the results of the statistical analysis of SSR data of $10 P$. patellaris occurrences as the effect of self-fertilisation. The result of the permutation test using 26 occurrences (Table 3) further substantiates the assumption. Within the set the mean differentiation increases from the gene pool to multi-locus level of genic integration by $9 \%$, only. It indicates that mainly self-fertilization resulting in homologous gene associations determines the differentiation. Several characteristics of inbreeders summarized by Jain (1975) also apply to P. patellaris. The population size is often small, and the colonizing ability is high as can be deduced from the very large 
Table 4 P. procumbens/P. webbiana. Permutation analysis of alleles over individuals within occurrences, of all individual genotypes among occurrences and the covariation of differentiation

\begin{tabular}{|c|c|c|c|c|c|}
\hline Permutations & Observed $\Delta_{\mathrm{SD}}$ values & Min & 0.95 confidence interval & Max & $p$ value \\
\hline \multicolumn{6}{|l|}{ Alleles over individuals within occurrences } \\
\hline Gene pool level & 0.4258 & & not affected & & \\
\hline Mean single locus genotypes & 0.4477 & 0.4425 & $0.4446 ; 0.4493$ & 0.4519 & $0.2642 \mathrm{~ns}$ \\
\hline Multilocus genotypes & 0.6049 & 0.5972 & $0.6004 ; 0.6069$ & 0.6094 & $0.2375 \mathrm{~ns}$ \\
\hline \multicolumn{6}{|l|}{ All individual genotypes between occurrences } \\
\hline Gene pool level & 0.4258 & 0.1669 & $0.1760 ; 0.2020$ & 0.2181 & $0.0000 * *_{-}>$ \\
\hline Mean single locus genotypes & 0.4477 & 0.2183 & $0.2270 ; 0.2492$ & 0.2641 & $0.0000 * *_{-}>$ \\
\hline Multilocus genotypes & 0.6049 & 0.4749 & $0.4803 ; 0.4964$ & 0.5065 & $0.0000 * *_{-}>$ \\
\hline Covariation of differentiation & Observed covariation value & & & & \\
\hline Gene pool versus mean single locus level & 1 & 0.9991 & $1 ; 1$ & 1 & $0.0000 * *_{-}>$ \\
\hline Gene pool versus multilocus level & 1 & 0.9970 & $0.9992 ; 1$ & 1 & $0.0000 * *_{-}>$ \\
\hline Mean single locus versus multilocus level & 1 & 0.9960 & $0.9995 ; 1$ & 1 & $0.0000 * *_{-}>$ \\
\hline
\end{tabular}

The values are based on 10,000 permutations for all 22 loci. The observed $\Delta_{\mathrm{SD}}$ value is shown for the three integration levels. The calculated minimum and maximum $\Delta_{\mathrm{SD}}$ values, the $95 \%$ confidence interval as well as the permutation $(p)$ values are shown. The symbols $* *_{-}>$(upper part of the distribution) and $* *<-$ (lower part of the distribution) indicate that fewer than $1 \%$ and more than $99 \%$ of the permutations yielded $\Delta_{\mathrm{SD}}$ values are significantly equal or greater than the observed distance. $* * p \leq 0.01$; ns $=$ not significant

distribution area compared to $P$. procumbens $/ P$. webbiana. However, only crossing experiments will reveal to what extent $P$. patellaris reproduces by selffertilization.

The statistical results presented in Table 4 underpin the observations of Frese (2002b) who crossed typical $P$. webbiana with typical $P$. procumbens plants using two phenotypically male sterile $P$. webbiana plants and succeeded to produce several hundreds of seeds. Within the set of plant material described in this paper cross-fertilization appears to be playing an important role in reproduction. The permutation of alleles over individuals within occurrences yielded non-significant permutation values suggesting that non-homologous gene association have a stronger impact on differentiation patterns than homologous gene associations. In addition, the large increase in the mean differentiation, by $42 \%$ from the gene pool to the multi-locus integration level, further confirms the assumption of preferential cross-fertilization within the $P$. procumbens/P. webbiana occurrences. The $\Delta_{\mathrm{j}}$ values (multilocus level) of the individual occurrences are high and deviate only slightly from the radius $\Delta_{\mathrm{SD}}=0.6049$. It shows that each of the occurrences has a specific genotypic composition and only moderately represents its complement. In fact, only a single multi-locus genotype was duplicated in the set of $P$. procumbens/
P. webbiana plants as opposed to 98 duplicated genotypes in the set of $458 P$. patellaris plants. This is a diversity pattern of a cross-fertilizing species.

Some characteristics of outbreeders apply to $P$. procumbens/P. webbiana. According to Jain (1975) outbreeders tend to form large, continuous populations characterized by a limited population turnover and the colonizing ability is less than that of inbreeding species. At least in Northwest Tenerife, P. procumbens forms large, more or less continuous and permanent populations. At the large geographic scale (countries) $P$. procumbens has a limited distribution compared to $P$. patellaris which is a striking finding. Because all Patellifolia species have very similar seed morphology and share similar habitats, one would expect they would have equal chance to spread over long distances. This is obviously not the case for $P$. procumbens and certainly not the case for $P$. webbiana. The latter mainly occurs on La Isleta (Gran Canaria), i.e. the distribution area of this taxon is extremely small.

Diversity patterns, genetic differentiation and conservation planning

Recommendations for conservation planning based on genetic criteria include the risk of being 


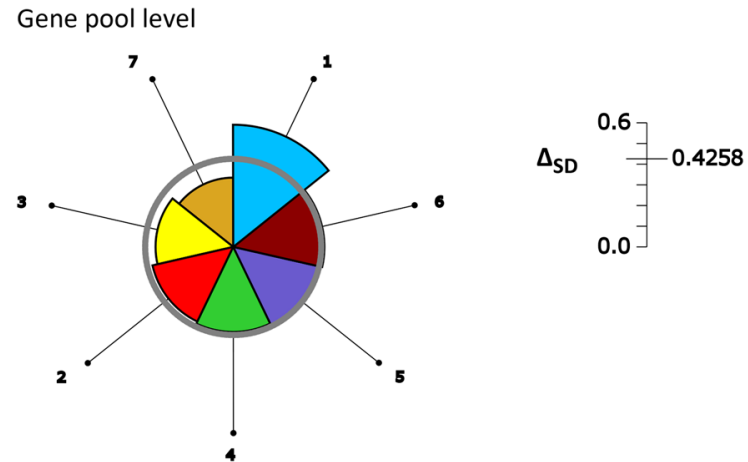

Mean single-locus level

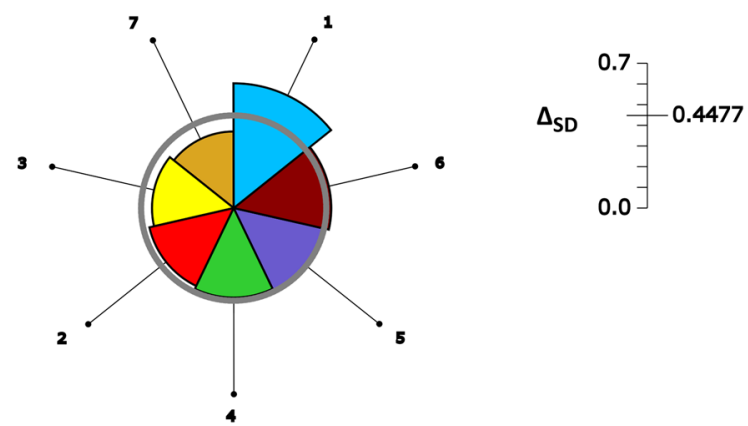

Multi-locus level
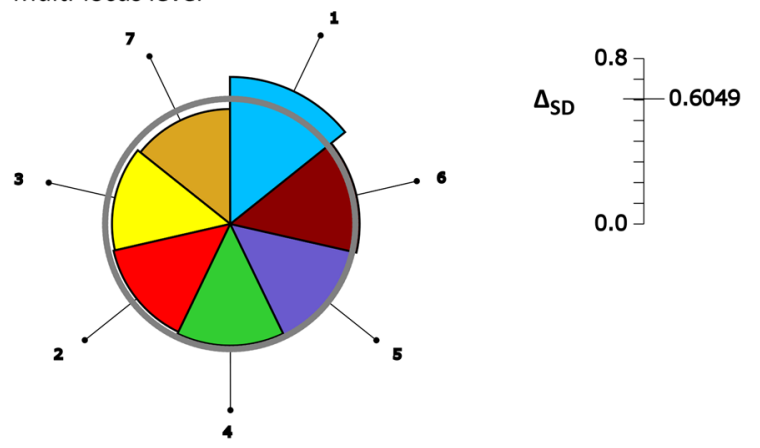

Fig. 4 Snail diagrams showing the differentiation between occurrences of $P$. procumbens/P. webbiana at the genepool (a), mean single-locus (b) and multi-locus (c) level. Contrary to Fig. 3 the colours have no specific meaning. A sector illustrates one of the occurrences. The radius of its sector equals the contribution of this occurrence to differentiation. The sectors are arranged according to the radius length clockwise starting with the largest radius to the right of 12:00 $\mathrm{h}$. The grey circle is equal to the weighted mean of the sector radii and marks $\Delta_{\mathrm{SD}}$. The $\Delta_{\mathrm{SD}^{-}}$value is shown on the bar next to the snail graph. Occurrence number 1 was sampled on Gran Canaria, occurrences number 2-7 were sampled on Tenerife. For more detail on occurrence numbers see Table 1

misinterpreted. Any recommendation in favour of a specific occurrence only means that this plant group is, at the best of our current knowledge, particularly suited to maintain the adaptability of a species. The recommendation cannot be understood as a categorisation of occurrences into indispensable and dispensable populations. Patellifolia populations are first and foremost part of the ecosystem and should be protected wherever they naturally occur. Genetic analyses can only assist identifying those populations within the distribution area which are, according to the current state of knowledge, of particular importance and which deserve specific attention by conservation agencies.

The factorial analysis revealed diversity distribution patterns which agree well with the geographic origin of the P. patellaris (Fig. 1) and P. procumbens/ $P$. webbiana samples (Fig. 2). P. patellaris samples from the Iberian Peninsula are subdivided into (1) an Eastern and (2) small Western group. The occurrence samples from the (3) Canary Islands overlap with the exception of the (4) El Hierro occurrence and form a larger swarm. Plants from (5) Madeira are interspersed into the swarm while the material from (6) Cape Verde is more separated. A set of MAWP should at least contain one occurrence of these six groups to capture genetic variation of adaptive traits which cannot be measured with the applied set of SSR marker.

In short-lived Patellifolia species the bulk of seeds produced at a location at the end of a season represents the gene pool of the respective occurrence and is the conservation unit. The following discussion concerns therefore the gene pool differentiation patterns. The search of genetic reserves localities can start with a pair of occurrences: one with the highest and one with the lowest $\Delta_{\mathrm{j}}$ value. The latter represents the distribution of genetic types in the complement best. The occurrence with the highest $\Delta_{\mathrm{j}}$ value is of particular interest as it points to an unusual genetic composition. This occurrence may have specific adaptive potential or interesting traits. Additional criteria, such as the likelihood that the minimum quality standards for genetic resources conservation (Iriondo et al. 2012) can be guaranteed by the responsible genetic reserve manager, can modify the ranking of occurrences during the decision-making process.

\section{P. patellaris}

On the Iberian Peninsula the size of $P$. patellaris occurrences is alarmingly small (Frese et al. 2017b) and if the occurrences get lost we will lose a relevant 

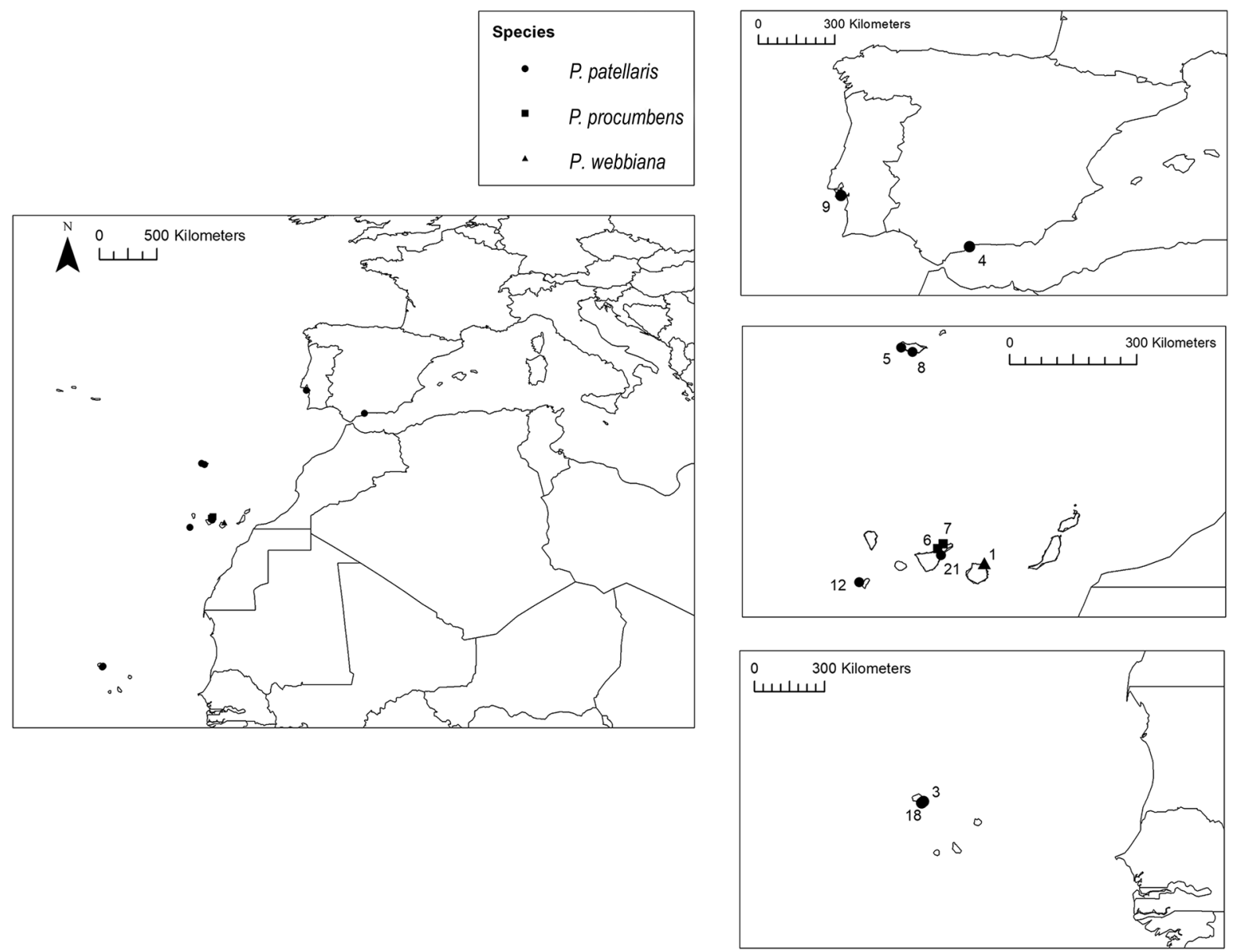

Fig. 5 The maps show the locations recommended genetic reserves sites. Numbers indicate either occurrence of $P$. patellaris or $P$. procumbens/P. webbiana as listed in Table 1.

fraction of the genetic diversity. If the conditions do not allow the conservation of all populations within the distribution area, genetic criteria can help taking the best possible decision. When the criterion "lowest/ highest $\Delta_{\mathrm{j}}$ value" is applied region-wise eight occurrences of $P$. patellaris qualify for proposing MAWP for the following areas: occurrence no. 9 and 4 (E and W Iberian Peninsula, respectively), occurrence no. 5 and 8 (Madeira), occurrence no. 18 and 3 (Cape Verde), and occurrence no. 12 and 21 (Canary Islands; gene pool level, Fig. 3a). The localities of the occurrences are shown in Fig. 5.
An overview map is displayed on the left. Right part from top to bottom: Iberian Peninsula, Madeira and Canary Islands, Cape Verde Islands

\section{P. procumbens/P. webbiana}

At Punta del Hidalgo (TPH), in Tenerife, P. procumbens forms plant canopies with few interstratified $P$. webbiana-like and $P$. patellaris plants. There is therefore the chance for interspecific crosses between the taxa. Interspecific crosses actually seem to happen as can be concluded from two observations. The $P$. procumbens material sampled at TPH (occurrence no. 6) clusters next to occurrence no. 1, i.e. P. webbiana sampled on Gran Canaria, indicating relatedness between occurrence no. 6 and 1 (Supplement 3). In fact, the genetic distance between occurrence no. 6 and 1 is $\Delta=0.6047$ and the lowest compared to the remaining five $P$. procumbens occurrences sampled on Tenerife. The community of Patellifolia plants at TPH 
is not only distinguished by a high morphological variation (Frese et al. 2017b) but also shows cytogenetic variation. At this site diploid, triploid and tetraploid plants were observed. The results indicate that interspecific hybridization generates novel genetic variation within the genus, which is positive for the species survival (Castro et al. 2017).

Occurrence no. 1 (P. webbiana) showed the highest $\Delta_{\mathrm{j}}$ value (Fig. $4 \mathrm{a}$ ) which can be explained by its almost unique composition at five of the 22 SSR loci (details not presented). In this particular case occurrence no. 1 is evidently a MAWP. P. procumbens occurrence no. 6 and 7 showed, respectively the largest and smallest distance to the complement and are also recommended as MAWP. Last not least, Beta macrocarpa is present at the TPH site (occurrence no. 6) which makes the site a candidate for the establishment of a multispecies genetic reserve. The locations of the occurrences are shown in Fig. 5.

This paper presents the first comprehensive study on patterns of genetic diversity of Patellifolia. The focus was set on the identification of a number of occurrences thought best suited to maintain the genetic diversity of the species within the European distribution area. Additional analysis will help to better understand the type and intensity of mechanisms generating fine-scale (Lara-Romero et al. 2016) and large-scale spatial genetic structures. With its scattered distribution in a large geographic area, research on the migration histories and genetic relationships between occurrences is not only a scientifically fascinating subject but also of relevance as to the identification of further localities for a future implementation of a comprehensive Patellifolia genetic reserve network.

It is necessary at this point to emphasize that, not solely for Patellifolia, conceptual and procedural tasks call for completion. $P$. patellaris occurrence no. 9 from West Portugal is a good example for pending issues. If the quality criteria for MAWP as defined by Maxted et al. (2015) are strictly applied, P. patellaris occurrence no. 9 from West Portugal would not qualify for the establishment of a genetic reserve due to the very low number of individuals. In Portugal the species is very rare, highly endangered and is thus a candidate for urgent species conservation actions. If the plant genetic resources conservation community does not recommend a genetic reserve site for occurrence no. 9 and if the nature conservation agencies are not aware of the conservation status of the species no actions will be taken at all. This case exemplarily underpins the need for systematic collaboration and information exchange between the plant genetic resources conservation and species conservation community, as well as with legislative authorities, which can be facilitated by the working group "Wild Species in Genetic Reserves" of the European Cooperative Programme for Plant Genetic Resources (ECPGR). Concepts for in situ conservation of CWR in Europe have been published (Maxted et al. 2015) and research gains momentum. However, the actual implementation is lagging behind and waiting the support of adequate public policies.

Acknowledgements The collecting was supported in Spain by Arnoldo Santos Guerra, Pablo Ferrer and Emilio Laguna and in Portugal by Humberto Nobrega, Gregório Freitas and João Alves. Lorenz Bülow and Elena Rey assisted in documenting and processing of the data. Silvia Castro provided valuable comments on the manuscript. The research work would not have been possible without the excellent laboratory work of Petra Hertling. We are very grateful for the support of all colleagues and the supporting technical staff. This research was co-funded by the European Cooperative Programme for Plant Genetic Resources (ECPGR), Rome, Italy.

Authors' contribution LF coordinated the work, performed the statistical analyses and drafted the paper. MN supervised the laboratory work, documented and processed the raw data. JMI, MLRT, MCD, and MÂAPC organised and conducted the collection trips. All persons contributed to the writing of the paper.

\section{Compliance with ethical standards}

The research work complies with ethical standards.

Conflict of interest The authors have no conflicts of interest to declare.

\section{References}

Aguirre-Gutiérrez J, van Treuren R, Hoekstra R, van Hintum TJL (2017) Crop wild relatives range shifts and conservation in Europe under climate change. Divers Distrib. https://doi.org/10.1111/ddi.12573

Anonymous (2017) Acta Plantarum, from 2007 on-"Scheda IPFI, Acta Plantarum". http://www.actaplantarum.org/ flora/flora_info.php?id=1187. Accessed 9 Nov 2017

Bilz M, Kell S, Maxted N, Lansdown RV (2011) European red list of vascular plants. Publications Office of the European Union, Luxembourg 
Castro S, Loureiro J, Iriondo J, Rubio Teso ML, Duarte MC, Romeiras MM, Pinheiro de Carvalho MAA, Santos Guerra A, Rey E, Frese L (2017) Cytogenetic diversity of Patellifolia species. Poster presented at 6th Global Botanic Gardens Congress, Botanic Gardens Conservation International, Conservatory and Botanical Garden of the City of Geneva, Switzerland, 26th-30th June 2017. http://www. 6gbgc.org/en/sample-page/. Accessed Aug 2017

de Vilmorin MJL (1923) L'hérédité chez la betterave cultivée. Thèse de Doctorat, soutenue le 11 juin 1923 devant la Faculté des Sciences de Paris. Gauthier-Villars et Cie, Paris

El Bahloul Y, Gaboun F (2013) Genetic structure analysis for Moroccan wild beet germplasm. In: Maggioni L, Frese L, Lipman E (eds) Report of a working group on beta and the world beta network. fourth joint meeting, 20-22 June 2012, Cappelle-en-Pévèle, France. Bioversity International, Rome, Italy, p 5

Enders M (2010) Entwicklung und Anwendung molekularer und informatorischer Werkzeuge zum genetischen Monitoring bei Wildrüben. Diplomarbeit im Fach Bioinformatik. Martin-Luther-Universität Halle-Wittenberg, Naturwissenschaftliche Fakultät III, Institut für Informatik, Halle, Germany

Eriksson G, Namkoong G, Roberds JH (1993) Dynamic gene conservation for uncertain futures. For Ecol Manag 62:15-37

EURISCO (2015) EURISCO Catalogue. http://eurisco.ecpgr. org. Accessed Jan 2015

Frese L (2002a) Combining static and dynamic management of PGR: a case study of Beta genetic resources. In: Engels JMM, Ramanatha Rao V, Brown AHD, Jackson MT (eds) Managing plant genetic diversity. CABI Publishing, Wallingford, pp 133-147

Frese L (2002b) Abschlußbericht zum Forschungs- und Entwicklungsvorhaben "GABI-BEET Genomanalyse der Zuckerrübe", Laufzeit 01.01.2000 bis 31.12.2002, gefördert durch das BMBF Förderkennzeichen: 0112283 A. Teilvorhaben: "Spaltende Populationen"

Frese L, Bülow L, Nachtigall M, Rubio Teso ML, Duarte MC, Rey E, Iriondo JM (2017a) Genetic diversity of Patellifolia patellaris from the Iberian Peninsula, a crop wild relative of cultivated beets. Euphytica 213:187. https://doi.org/10. 1007/s10681-017-1942-0

Frese L, Bülow L, Castro S, Duarte MC, Iriondo JM, Lohwasser U, Loureiro J, Maxted N, Nachtigall M, Nobrega H, Pinheiro de Carvalho MÂA, Santos Guerra A, Romeiras MM, Rubio ML, Rey E (2017b) Genetic diversity of Patellifolia (GeDiPa). Final Activity Report. ECPGR Activity Grant Scheme-First Call, 2014

GBIF (2015) GBIF home page. http://gbif.org. Accessed Jan 2015

Gillet EM (2013) DifferInt: compositional differentiation among populations at three levels of genetic integration. Mol Ecol Resour 13:953-964

Gillet EM, Gregorius H-R (2008) Measuring differentiation among populations at different levels of genetic integration. BMC Genet 9:60

Gregorius H-R, Gillet EM, Ziehe M (2003) Measuring differences of trait distributions between populations. Biom $\mathrm{J}$ 45:959-973
Gregorius H-R, Gillet EM, Ziehe M (2014) Relating measures of compositional differentiations among communities to conceptual models of migration and selection. Ecol Model 279:24-35

GRIN (2015) GRIN home page. https://www.ars-grin.gov/. Accessed Jan 2015

Hammer K (2001) Chenopodiaceae. In: Hanelt P, Institute of Plant Genetics and Crop Plant Research (eds) Mansfeld's encyclopedia of agricultural and horticultural crops (except ornamentals). Springer, Berlin, pp 235-241

Harlan J, de Wet J (1971) Towards a rational classification of cultivated plants. Taxon 20:509-517

Hohmann S, Kadereit JW, Kadereit G (2006) Understanding mediterranean-Californian disjunctions: molecular evidence from Chenopodiaceae-Betoideae. Taxon 55:67-78

IDBB (2015) IDBB home page. http://idbb.julius-kuehn.de/ idbb. Accessed Jan 2015

Iriondo JM, Maxted N, Kell SP, Ford-Lloyd BV, Lara-Romero C, Labokas J, Magos Brehm J (2012) Quality standards for genetic reserve conservation of crop wild relatives. In: Maxted N, Dulloo ME, Ford-Lloyd BV, Frese L, Iriondo JM, Pinheiro de Carvalho MÂA (eds) Agrobiodiversity conservation: securing the diversity of crop wild relatives and landraces. CAB International, Wallingford, pp 72-77

Jain SK (1975) Population structure and the effects of breeding systems. In: Frankel OH, Hawkes JG (eds) Crop genetic resources for today and tomorrow. International Biological Programme 2. Cambridge University Press, Cambridge, pp 15-36

Jung C, Pillen K, Frese L, Fähr S, Melchinger A (1993) Phylogenetic relationships between cultivated and wild species of the genus Beta revealed by DNA fingerprinting. Theor Appl Genet 86:449-457

Kadereit G, Hohmann S, Kadereit JW (2006) A synopsis of Chenopodiaceae subf. Betoideae and notes on taxonomy of Beta. Willdenowia 36:9-19

Kell S, Maxted N, Frese L, Iriondo JM (2012) In situ conservation of crop wild relatives: a strategy for identifying priority genetic reserves sites. In: Maxted N, Dulloo ME, Ford-Lloyd BV, Frese L, Iriondo JM, Pinheiro de Carvalho MÂA (eds) Agrobiodiversity conservation: securing the diversity of crop wild relatives and landraces. CABI Publishing, Wallingford, pp 7-19

Kleinschmit JRG, Kownatzki D, Gregorius H-R (2004) Adaptational characteristics of autochthonous populationsconsequences for provenance delineation. For Ecol Manag 197:213-224

Lange W, Brandenburg WA, De Bock TSM (1999) Taxonomy and cultonomy of beet (Beta vulgaris L.). Bot J Linn Soc 130:81-96

Lara-Romero C, García-Fernández A, Robledo-Arnuncio JJ, Roumet M, Morente-López J, López-Gil A, Iriondo JM (2016) Individual spatial aggregation correlates with between-population variation in fine-scale genetic structure of Silene ciliata (Caryophyllaceae). Heredity 116:417-423

Löptien H (1984) Breeding nematode-resistant beets. II. Investigations into the inheritance of resistance to Heterodera schachtii Schm. in wild species of the section Patellares. Z Pflanzenzüchtg 93:237-245 
Manel S, Schwartz MK, Luikart G, Taberlet P (2003) Landscape genetics: combining landscape ecology and population genetics. Trends Ecol Evol 18:189-197

Maxted N, Hawkes JG, Ford-Lloyd BV, Williams JT (1997) Chapter 22. A practical model for in situ genetic conservation. In: Maxted N, Ford-Lloyd BV, Hawkes JG (eds) Plant genetic conservation: the in situ approach. Kluwer Academic Publishers, London, pp 339-364

Maxted N, Iriondo JM, Dulloo E, Lane A (2008) Introduction: the integration of PGR conservation with protected area management. In: Iriondo JM, Maxted N, Dulloo E (eds) Plant genetic population management. CABI, Wallingford, pp 1-22

Maxted N, Avagyan A, Frese L, Iriondo JM, Magos Brehm J, Singer A, Kell SP (2015) ECPGR concept for in situ conservation of crop wild relatives in Europe. Wild species in genetic reserves working group. Rome, European Cooperative Programme for Plant Genetic Resources

Nachtigall N, Bülow L, Schubert J, Frese L (2016) Development of SSR markers for the genus Patellifolia (Chenopodiaceae). Appl Plant Sci 4:8. https://doi.org/10.3732/apps. 1600040

Nachtigall M, Frese L, Bülow L, Rey E (2018) Microsatellite marker data of Patellifolia patellaris, P. procumbens and P. webbiana. [dataset]. Quedlinburg. Open Agrar Repository. https://doi.org/10.5073/20180816-152451

Nei M (1973) Analysis of gene diversity in subdivided populations. Proc Natl Acad Sci USA 70:3321-3323

Panella LW, Lewellen RT (2007) Broadening the genetic base of sugar beet: introgression from wild relatives. Euphytica 154:383-400. https://doi.org/10.1007/s10681-006-9209-1

Parmesan C, Hanley ME (2015) Plants and climate change: complexities and surprises. Ann Bot 116:849-864. https:// doi.org/10.1093/aob/mcv169
Perrier X, Jacquemound-Collet JP (2006) DARwin software. http://darwin.cirad.fr/darwin. Accessed 10 Oct 2010

Raab-Straube EV, Raus T. (eds) (2016) Euro + Med-Checklist Notulae, 6 [Notulae ad floram euromediterraneam pertinentes No. 35]. Willdenowia, vol 46, pp 423-442. http:// dx.doi.org/10.3372/wi.46.46310

Romeiras MM, Vieira A, Silva DN, Moura M, Santos-Guerra A, Batista D, Duarte MC, Paulo OS (2016) Evolutionary and biogeographic insights on the macaronesian Beta-Patellifolia species (Amaranthaceae) from a time-scaled molecular phylogeny. PLoS ONE 11(3):e0152456. https://doi. org/10.1371/journal.pone.0152456

Saghai-Maroof MA, Soliman KM, Jorgensen RA, Allard RW (1984) Ribosomal DNA spacer-length polymorphisms in barley: mendelian inheritance, chromosomal location, and population dynamics. Proc Natl Acad Sci USA 81:8014-8018

Scott AJ, Ford-Lloyd BV, Williams JT (1977) Patellifolia, nomen novum (Chenopodiaceae). Taxon 26(2-3):284

Thulin M, Rydberg A, Thiede J (2010) Identity of Tetragonia pentandra and taxonomy and distribution of Patellifolia (Chenopodiaceae). Willdenowia 40(1):5-11. https://doi. org/10.3372/wi.40.40101

Weir BS, Cockerham CC (1984) Estimating F-Statistics for the analysis of population structure. Evolution 38:1358-1370

Winner C (1981) Zuckerrübenbau. DLG-Verlag, Frankfurt am Main

Zehm A, Weber G (2013) Umsetzung eines landesweiten floristischen Artenhilfsprogramms-Konzepte und Erfahrungen. Anliegen Nat 35:40-54 